\title{
Utilization of macrominerals and trace elements in pregnant heifers with distinct feed efficiencies
}

\author{
R. S. Dias, ${ }^{*}$ Y. R. Montanholi, ${ }^{\star} †$ S. Lopez,$\ddagger^{1}$ B. Smith, ${ }^{\star} \S$ S. P. Miller, ${ }^{*} \#$ and J. France ${ }^{*}$ \\ *Department of Animal Biosciences, University of Guelph, Guelph N1G 2W1, ON, Canada \\ †Department of Plant and Animal Sciences, Dalhousie University, Truro B2N 5E3, NS, Canada \\ łInstituto de Ganadería de Montaña (IGM) CSIC-Universidad de León, Departamento de Producción Animal, Universidad de León, \\ E-24071 León, Spain \\ §Monsanto, Headingley, R3T 6E3, MB, Canada \\ \#Invermay Agricultural Centre, AgResearch Limited, Mosgiel, 9053 New Zealand
}

\section{ABSTRACT}

The objective of the study was to evaluate utilization of dietary minerals and trace elements in pregnant heifers with distinct residual feed intakes (RFI). Feed intake, body weight (BW), and body composition traits were recorded in 36 crossbred heifers over a period of 37 wk, starting shortly after weaning at $8.3(0.10$; standard deviation) mo of age with an average BW of 276 (7.8) $\mathrm{kg}$. Both BW and body composition were monitored regularly throughout the study, whereas individual feed intake was assessed during the last $84 \mathrm{~d}$ of the trial. Data recorded were used to calculate RFI for each heifer. Heifers were ranked based on RFI and assigned to high $(\mathrm{n}=14)$ or low $(\mathrm{n}=10)$ RFI groups. After the RFI study, 24 selected heifers [age 18.2 (0.14) mo; 87.5 (4.74) d in gestation; 497 (8.5) $\mathrm{kg}$ of BW] were used in an indirect digestibility trial (lignin as internal marker). Heifers were fed a ration containing corn silage, haylage, and a mineral premix in which $\mathrm{Ca}, \mathrm{P}, \mathrm{K}, \mathrm{Na}$, $\mathrm{Mg}, \mathrm{S}, \mathrm{Cu}, \mathrm{Fe}, \mathrm{Mn}, \mathrm{Mo}$, Se, Zn, and Co were provided in the diet according to National Research Council requirements of pregnant replacement heifers. The digestibility trial lasted $1 \mathrm{wk}$, during which samples of feces were gathered twice daily, and blood and liver biopsy samples were collected on the last day. We noted no significant differences between low- and high-RFI heifers in dry matter digestibility. Apparent absorption of $\mathrm{Cu}, \mathrm{Zn}$, and $\mathrm{Mn}$ was increased in heifers with low RFI, and apparent absorption of Co tended to be greater for these animals. Concentrations of macrominerals and trace elements in serum of pregnant heifers were similar for both groups except for Se, which was increased in the serum of low-RFI heifers. Liver concentrations of $\mathrm{Cu}, \mathrm{Fe}, \mathrm{Mn}, \mathrm{Mo}$, Se, and $\mathrm{Zn}$ did not differ between low-

Received December 22, 2015.

Accepted March 4, 2016.

${ }^{1}$ Corresponding author: s.lopez@unileon.es and high-RFI heifers. In conclusion, whereas improved absorption of some trace elements $(\mathrm{Cu}, \mathrm{Zn}, \mathrm{Mn}$, and Co) and increased Se serum concentration appear to be associated with superior feed efficiency in pregnant heifers, further studies are needed to investigate the causality of such relationships.

Key words: digestibility, internal marker, mineral status, residual feed intake, trace element utilization

\section{INTRODUCTION}

Residual feed intake (RFI), representing the individual animal variation in feed intake above or below that predicted on the basis of size and growth, has become a useful, sensitive, and precise measurement of feed efficiency in cattle (Koch et al., 1963; Richardson and Herd, 2004; Hill, 2012). Efficient animals eat less than expected and therefore have a negative or low RFI. Residual feed intake is independent of production traits and animal size, and thus an interesting trait to be improved in cattle. Genetic selection based on RFI may result in substantial reductions in costs of production, manure nitrogen, phosphorus excretion, and methane emissions by livestock (Herd et al., 2003; Hegarty et al., 2007; Basarab et al., 2013; Knapp et al., 2014). Studies have reported some of the biochemical and physiological mechanisms controlling RFI (e.g., Herd et al., 2004; Kolath et al., 2006; Bottje and Carstens, 2012; Davis et al., 2012; Meyer et al., 2012; Montanholi et al., 2013a), but available information is still scarce regarding a plausible link between mineral utilization and RFI.

Minerals and trace elements are essential for several important physiological functions in ruminants (Suttle, 2010). Adequate mineral nutrition is essential for optimal performance (Spears, 1996), and imbalances can affect cattle health (Underwood and Suttle, 1999). In the pregnant animal, a healthy fetus relies on the maternal system for an adequate supply of trace elements and other nutrients (Hidiroglou and Knipfel, 1981). An 
unbalanced supply of minerals during pregnancy can be detrimental to the health and development of both the fetus and neonate (Hostetler et al., 2003). Based on the hypothesis that differences in RFI could be related to mineral utilization, the objective of our study was to assess utilization of minerals and trace elements in pregnant heifers with distinct RFI.

\section{MATERIALS AND METHODS}

Twenty-four pregnant heifers were used in a digestibility trial. These animals had been selected from a group of 36 crossbred replacement heifers previously used in a study to determine RFI. The average breed composition of the 36 crossbred heifers was $64.9 \%$ Angus, $20.5 \%$ Simmental, and $14.6 \%$ other European breeds. The experimental procedures, conducted at Elora Beef Cattle Research Centre, University of Guelph, followed the Canadian Council on Animal Care (1993) guidelines, and were approved by the University of Guelph Animal Care Committee.

\section{RFI}

Postweaning RFI was determined in a herd of 36 heifers housed in six 10.8- $\times 5.4-\mathrm{m}$ outdoor pens with a sheltered area $\left(29.2 \mathrm{~m}^{2}\right)$, each pen accommodating a group of 6 animals. Pens were bedded with wheat straw that was topped up based on perceived moisture. Data to assess RFI were collected over a period of $37 \mathrm{wk}$, split into 2 phases. In both phases, heifers were fed ad libitum the diet described in Table 1 . The first phase started in December 2011 shortly after weaning [with an average age of $8.3(0.10 ; \mathrm{SD})$ mo and an average BW of 276 (7.8) kg], and lasted 25 wk (until June 2012) when the heifers reached 420 (8.1) kg of BW. During this first phase, feed was offered on shared bunks and only growth performance traits (BW and ultrasound for body composition) were measured. Heifers were weighed on $\mathrm{d} 1$ and 28 , and weekly thereafter until wk 25. Body composition traits were determined by ultrasonic scans on d 1 and then every $28 \mathrm{~d}$ until wk 20 . In the second phase of the RFI assessment, both feed intake and growth performance traits were recorded. The second phase lasted $12 \mathrm{wk}$, from the end of the previous phase (June 2012) to wk 37 (September 2012), when the heifers were 17.1 (0.10) mo old and weighed 493 (9.9) kg. During this second phase, heifers were bred by AI. Breeding occurred 10 to $16 \mathrm{~h}$ after estrus was detected by monitoring heat signs twice daily (0800 and $1600 \mathrm{~h}$ ) and using a teaser bull guided by a herdsman. Body weight was recorded weekly during the first $4 \mathrm{wk}$, and then every $2 \mathrm{wk}$ until the end of this phase. All heifers carried a single fetus. Ultrasonic measure- ments of body composition were taken the first day and then every 28 d until the end of the trial. During phase 2 , animals were kept in the same pens, but each heifer had individual feed access through the use of Calan gates (American Calan Inc., Northwood, NH). Daily feed offered was recorded, and weekly or twice weekly feed refusals were collected and weighed to calculate feed intake. Heifers were fed 105 to $110 \%$ of their expected intake based on previous feed intake assessments to allow for ad libitum consumption. Ultrasonic scans were taken for the measurements of body composition in both phases. Backfat thickness, rump fat thickness, intramuscular fat, and rib-eye (longissimus dorsi) area were determined using an ultrasound unit (Aloka SSD500, Tokyo, Japan) and rib-eye, rump, and backfat images yielded by this system were interpreted using the AUSKey program (Animal Ultrasound Services, Ithaca, NY; Montanholi et al., 2009). Intramuscular fat was

Table 1. Ingredient composition and chemical analysis of the diet

\begin{tabular}{|c|c|}
\hline Item & Measurement \\
\hline \multicolumn{2}{|c|}{ Ingredient composition ( $\mathrm{g} / \mathrm{kg}$ of $\mathrm{DM}$ in diet) } \\
\hline Whole corn silage & 503 \\
\hline Haylage $^{1}$ & 482 \\
\hline Trace mineralized salt ${ }^{2}$ & 9 \\
\hline Calcium phosphate $^{3}$ & 6 \\
\hline \multicolumn{2}{|c|}{$\begin{array}{l}\text { Chemical composition ( } \mathrm{g} / \mathrm{kg} \text { of DM unless otherwise } \\
\text { stated) }\end{array}$} \\
\hline $\mathrm{DM}(\mathrm{g} / \mathrm{kg})$ & 358 \\
\hline $\mathrm{CP}$ & 155 \\
\hline $\mathrm{NDF}$ & 416 \\
\hline $\mathrm{ADF}$ & 331 \\
\hline Lignin & 79.3 \\
\hline $\mathrm{TDN}^{4}$ & 657 \\
\hline $\mathrm{NE}_{\mathrm{G}}^{4}(\mathrm{Mcal} / \mathrm{kg}$ of $\mathrm{DM})$ & 0.99 \\
\hline $\mathrm{NE}_{\mathrm{L}}^{4}(\mathrm{Mcal} / \mathrm{kg}$ of $\mathrm{DM})$ & 1.35 \\
\hline Calcium & 12.2 \\
\hline Phosphorus & 4.7 \\
\hline Potassium & 19.2 \\
\hline Sodium & 5.5 \\
\hline Sulfur & 2.1 \\
\hline Magnesium & 2.6 \\
\hline Copper $(\mathrm{mg} / \mathrm{kg}$ of DM) & 25.3 \\
\hline Iron $(\mathrm{mg} / \mathrm{kg}$ of $\mathrm{DM})$ & 345 \\
\hline Manganese (mg/kg of DM) & 71.8 \\
\hline Molybdenum (mg/kg of DM) & 1.70 \\
\hline Selenium $(\mathrm{mg} / \mathrm{kg}$ of $\mathrm{DM})$ & 0.12 \\
\hline Zinc $(\mathrm{mg} / \mathrm{kg}$ of DM) & 67.5 \\
\hline Cobalt $(\mathrm{mg} / \mathrm{kg}$ of $\mathrm{DM})$ & 0.53 \\
\hline
\end{tabular}

${ }^{1}$ Haylage composed of $85 \%$ orchard grass, $5 \%$ timothy, $5 \%$ meadow brome and $5 \%$ ladino and red clover.

${ }^{2}$ Composition (per kg of product): $965 \mathrm{~g}$ of $\mathrm{NaCl}, 7.5 \mathrm{~g}$ of $\mathrm{Zn}, 5 \mathrm{~g}$ of $\mathrm{Mn}, 2.5 \mathrm{~g}$ of $\mathrm{Cu}, 1.6 \mathrm{~g}$ of $\mathrm{Fe}, 0.07 \mathrm{~g}$ of I, and $0.04 \mathrm{~g}$ of Co. Ingredients: zinc oxide, manganese oxide, copper oxide, iron oxide, ferrous carbonate, cobalt carbonate, and ethylenediamine dihydroiodide.

${ }^{3}$ Contained $170 \mathrm{~g}$ of $\mathrm{Ca}$ and $210 \mathrm{~g}$ of $\mathrm{P}$ per kilogram.

${ }^{4}$ Calculated from ADF using the equations of Agro-Food Laboratories Inc. (Guelph, ON, Canada), available at http://www.agtest.com/articles/FEEDANDFORAGESCALCULATIONS_new.pdf (accessed Dec. $12,2015)$. 
estimated using CPEC software (Cattle Performance Enhancement Company, Oakley, CA).

Average daily gain was determined by linear regression of BW against days on test. A similar approach was applied to the body composition measurements determined by ultrasound methods. Several candidate models were tested to predict feed intake from the animal's BW and performance (ADG and changes in body composition), following the approach of Montanholi et al. (2009) and Sainz (2012). Multiple linear regression was performed using the GLM procedure of SAS (SAS Institute Inc., 2011), and the selected model (based on information criteria) to predict expected feed intake for the animal's level of production was

$$
\begin{gathered}
\mathrm{eDMI}=7.23+0.0206 \mathrm{ABW}_{\mathrm{P} 1}-0.0148 \mathrm{ABW}_{\mathrm{P} 2} \\
+1.66 \mathrm{ADG}_{\mathrm{P} 1}+0.872 \mathrm{ADG}_{\mathrm{P} 2}+5.81 \mathrm{BFT}_{\mathrm{P} 1} \\
+7.47 \mathrm{BFT}_{\mathrm{P} 2}+0.0204 \mathrm{RBE}_{\mathrm{P} 1}-0.0119 \mathrm{RBE}_{\mathrm{P} 2} \\
-6.54 \mathrm{RUP}_{\mathrm{P} 2}\left(\mathrm{n}=36 ; \mathrm{R}^{2}=0.34\right. \\
\quad \mathrm{SE} \text { of the regression }=0.82),
\end{gathered}
$$

where eDMI is expected DMI ( $\mathrm{kg}$ of $\mathrm{DMI} / \mathrm{d}), \mathrm{ABW}$ is average body weight $(\mathrm{kg}), \mathrm{ADG}$ is in $\mathrm{kg} / \mathrm{d}, \mathrm{BFT}$ is total backfat thickness gain (mm), RBE is total ribeye area gain $\left(\mathrm{cm}^{2}\right)$, RUP is total rump fat thickness gain $(\mathrm{mm})$, and the subscripts indicate the period when the explanatory variable was recorded, either during phase $1(\mathrm{P} 1)$ or phase $2(\mathrm{P} 2)$ of the trial. The constants represent the intercept (7.23) and the linear regression coefficient for each explanatory variable. Residuals of this regression equation [difference between the observed (measured) and the expected feed intake] were used to calculate RFI ( $\mathrm{kg}$ of $\mathrm{DM} / \mathrm{d}$ ) for each heifer $(\mathrm{RFI}=\mathrm{DMI}-\mathrm{eDMI})$. A positive RFI indicates an inferior feed efficiency (the animal eats more feed than expected), whereas a negative RFI is an indicator of a superior feed efficiency (the animal eats less feed than expected).

Heifers were ranked by RFI and assigned to high (inefficient) RFI (RFI $>0.2 \mathrm{~kg}$ of $\mathrm{DM} / \mathrm{d}, \mathrm{n}=14$ ), and low (RFI $<-0.2 \mathrm{~kg}$ of DM/d; $\mathrm{n}=10)$ RFI groups (Montanholi et al., 2013b; Gonano et al., 2014). As a result, a total of 24 heifers were selected based on their RFI, and classified as low (10 heifers) or high (14 heifers) RFI, which provided the 2 experimental groups for the digestibility trial.

\section{Digestibility Trial}

Immediately after the RFI study described above (in October 2012), the 24 pregnant heifers [18.2 (0.14) mo old; 87.5 (4.74) d in gestation; 497 (8.5) $\mathrm{kg}$ of BW] selected for their RFI were used in a 7-d digestibility trial (indirect method using lignin as a marker). Heifers were housed in $10-\times 3-\mathrm{m}$ individual stalls partially covered and bedded with wood shavings. Heifers were fed twice daily the diet described in Table 1, and feed refusals were collected every $24 \mathrm{~h}$ for feed intake calculation. Samples of feed and orts were collected daily, and all the samples were pooled at the end of the trial for further analysis. Defecation was monitored for 2 periods of $1.5 \mathrm{~h}$ each day (0600 to $0730 \mathrm{~h}$ and 1800 to $1930 \mathrm{~h}$ ) over 7 consecutive days. About $100 \mathrm{~g}$ of fresh feces was immediately and thoroughly collected from each individual defecation in an effort to avoid decomposition and air exposure and to obtain a representative sample. After collecting the samples, the remaining manure was removed to avoid sample contamination. Subsamples were mixed to form a single composite and $\sim 350 \mathrm{~g}$ of this composite was stored at $-20^{\circ} \mathrm{C}$ and kept until the end of the week, when daily samples for $7 \mathrm{~d}$ were pooled.

After the experimental period, all samples (feces, feed, and orts) were sent to SGS Agri-Food Laboratories Inc. (Guelph, ON, Canada) for analysis. Feed, orts, and feces were oven-dried at $60^{\circ} \mathrm{C}$ to a constant weight to determine DM content, and then dry samples were analyzed to determine chemical composition. Trace elements were analyzed using inductively coupled plasma mass spectrometry (ICPMS), and macrominerals according to AOAC International (2006) guidelines (methods 985.01 for Ca, P, K, and $\mathrm{Mg}, 923.01$ for $\mathrm{S}$, and 969.10 for $\mathrm{Na}$ ). The analysis of $\mathrm{CP}$ in feed was carried out according to AOAC official method 990.03. Neutral detergent fiber was determined according to AOAC official method 2002.04, whereas AOAC official method 973.18 was used for the analyses of ADF and ADL. Sequential fiber (NDF - ADF - ADL) analysis was performed using an Ankom fiber analyzer (Ankom Technology Corporation, Fairport, NY.

Acid detergent lignin was used as an internal marker (Kotb and Luckey, 1972). Digestibility (g of feed DM absorbed/g of feed DM ingested) was therefore calculated as

$$
\mathrm{DM} \text { digestibility }=1-\left(\mathrm{ADL}_{\text {feed }} / \mathrm{ADL}_{\text {feces }}\right) \text {, }
$$

where $\mathrm{ADL}_{\text {feed }}$ and $\mathrm{ADL}_{\text {feces }}$ are the lignin contents ( $\mathrm{g}$ of lignin $/ \mathrm{kg}$ of DM) in feed and feces DM, respectively.

Mineral apparent absorption (g of mineral absorbed/g of mineral ingested) was estimated using the internal marker method as

Mineral apparent absorption $=$

$$
1-\left(\mathrm{ADL}_{\text {feed }} / \mathrm{ADL}_{\text {feces }}\right) \times\left(\mathrm{MIN}_{\text {feces }} / \mathrm{MIN}_{\text {feed }}\right) \text {, }
$$


where $\mathrm{MIN}_{\text {feed }}$ and $\mathrm{MIN}_{\text {feces }}$ are the mineral contents ( $\mathrm{g}$ of mineral $/ \mathrm{kg}$ of $\mathrm{DM}$ ) in feed and feces $\mathrm{DM}$, respectively.

Water consumed by the animals was analyzed for Ca, $\mathrm{Cu}, \mathrm{Fe}, \mathrm{Mg}, \mathrm{Mn}, \mathrm{Mo}, \mathrm{K}, \mathrm{Na}$, and $\mathrm{Zn}$ by ALS Environmental (Waterloo, ON, Canada). Mineral concentrations were determined using an unfiltered aqueous sample digested with nitric acid and then analyzed directly by ICPMS.

\section{Blood Serum}

Blood samples were collected by jugular venipuncture into sterile Vacutainer tubes (BD Biosciences, Mississauga, ON, Canada) mounted on an 18-gauge $\times 2.5$-cm needle (Montanholi et al., 2013a). Blood was collected in the morning $(0600 \mathrm{~h})$ of the last day of the digestibility trial. Samples were left at room temperature for 25 min for the blood to clot and then serum was separated by centrifugation at $3,750 \times g$ for $25 \mathrm{~min}$ and stored at $-80^{\circ} \mathrm{C}$ before being sent to the University of Guelph Laboratory Services for analysis of $\mathrm{Cu}, \mathrm{Fe}, \mathrm{Mn}, \mathrm{Mo}, \mathrm{Zn}$, and Se by ICPMS.

\section{Liver Biopsy}

Liver samples were taken from each heifer at the end of the digestibility trial. Liver tissue was extracted via biopsy as described by Greenwood et al. (2009). Briefly, heifers were intravenously sedated with xylazine $(0.02$ $\mathrm{mg} / \mathrm{kg}$ of BW; Rompun, Bayer HealthCare, Toronto, ON, Canada). The site of incision was shaved and disinfected using chlorhexidine solution $(0.5 \%$ chlorhexidine gluconate) and local anesthesia (approximately $10 \mathrm{~mL}$ per heifer; Xylocaine, containing 2\% lidocaine hydrochloride injection USP, AstraZeneca Canada Inc., Mississauga, ON, Canada) was administered. An incision was made into the intercostal space and a sample of approximately $3 \mathrm{~g}$ of liver tissue was extracted using a trocar (length of $30 \mathrm{~cm}$; diameter of $1 \mathrm{~cm}$ ). Approximately $0.5 \mathrm{~g}$ of fresh tissue was snap frozen in liquid nitrogen and stored at $-80^{\circ} \mathrm{C}$. The incision was sutured using surgical staples (American Health Company, Mettawa, IL) and heifers were monitored until healing was complete. Samples were sent the University of Guelph Laboratory Services for analysis of $\mathrm{Cu}, \mathrm{Fe}, \mathrm{Mn}$, Mo, Zn, Co, and Se in wet tissue by ICPMS.

\section{Statistical Analysis}

All statistical analyses were undertaken using SAS (SAS Institute Inc., 2011). Multiple linear regression (PROC GLM in SAS) was used to fit the equation to predict expected DMI from performance and body
Table 2. Analysis of water consumed by animals in the study

\begin{tabular}{lcc}
\hline Minerals in water & $\begin{array}{c}\text { Sample analysis } \\
(\mathrm{mg} / \mathrm{L})\end{array}$ & $\begin{array}{c}\text { Recommended maximum } \\
\text { concentrations }^{1}(\mathrm{mg} / \mathrm{L})\end{array}$ \\
\hline Calcium & 34.8 & 1,000 \\
Copper & 0.0021 & 1.0 \\
Iron & 0.063 & 0.4 \\
Magnesium & 19.2 & 1,000 \\
Manganese & 0.047 & 0.05 \\
Molybdenum & 0.0049 & 0.06 \\
Potassium & $<1.0$ & 20 \\
Sodium & 24.8 & 800 \\
Zinc & 0.054 & 5.0 \\
Sulfate & 4.6 & 500 \\
\hline
\end{tabular}

${ }^{1}$ As in Puls (1994).

composition traits. The MIXED procedure of SAS was used to analyze the comparisons between low and high RFI groups, by fitting the model

$$
y_{i j}=\mu+\text { RFIgroup }_{i}+\varepsilon_{i j},
$$

where $y_{i j}$ is the variable measured (mineral intake, apparent absorption or concentration in serum or liver) in the $j$ th heifer, belonging to the $i$ th RFI group; $\mu$ is the overall mean; RFIgroup $i$ is the fixed effect of the $i$ th RFI group; and $\varepsilon_{i j}$ is the random residual effect due to individual variability within each group. Least squares means for each RFI group are reported. Differences were considered statistically significant when $P<$ 0.05 and a trend when $0.05<P<0.10$. The Pearson product-moment correlation coefficient was computed with PROC CORR.

\section{RESULTS}

Chemical composition of the diet (including concentrations of all minerals) is shown in Table 1, and mineral and trace element concentrations in water are presented in Table 2.

As expected, DMI was different $(P<0.001)$ between groups during the trial $[8.5(\mathrm{SEM}=0.32)$ and 11.1 $(\mathrm{SEM}=0.36) \mathrm{kg} / \mathrm{d}$ for the low- and high-RFI heifers, respectively], resulting in the different RFI estimates shown in Table 3. Apparent DM digestibility was similar $(P=0.88)$ in both RFI groups (Table 3). We noted no differences $(P>0.10)$ between both groups of animals in the apparent absorption of Fe, Mo, and Se (Table 3). In contrast, apparent absorption of $\mathrm{Cu}, \mathrm{Zn}$, and Mn were increased in low-RFI heifers $(P<0.05)$. A tendency $(P=0.07)$ for differences was noted between groups in the apparent absorption of Co (Table 3), suggesting higher absorption of Co in low-RFI heifers. Apparent absorption of $\mathrm{P}, \mathrm{K}, \mathrm{Ca}, \mathrm{Mg}, \mathrm{S}$, and $\mathrm{Na}$ were similar for both groups of heifers $(P>0.10)$. 
Table 3. Least squares means ( \pm SEM) for DM and mineral apparent absorption in the gastro-intestinal tract (all expressed as g apparently absorbed/g ingested, unless otherwise noted) in pregnant heifers with low and high residual feed intake (RFI)

\begin{tabular}{lcrr}
\hline Item & Low RFI & \multicolumn{1}{c}{ High RFI } & $P$-value \\
\hline RFI $(k g$ of DM/d) & $-1.18 \pm 0.124$ & $1.24 \pm 0.159$ & $<0.001$ \\
DM digestibility & $0.628 \pm 0.0131$ & $0.631 \pm 0.0111$ & 0.876 \\
Copper & $0.095 \pm 0.0558$ & $-0.058 \pm 0.0471$ & 0.048 \\
Iron & $0.177 \pm 0.0814$ & $0.044 \pm 0.0688$ & 0.226 \\
Manganese & $0.273 \pm 0.0414$ & $0.143 \pm 0.0350$ & 0.025 \\
Molybdenum & $0.275 \pm 0.1078$ & $0.321 \pm 0.0911$ & 0.749 \\
Selenium & $0.312 \pm 0.0566$ & $0.374 \pm 0.0478$ & 0.410 \\
Zinc & $0.269 \pm 0.0517$ & $0.099 \pm 0.0437$ & 0.020 \\
Cobalt & $0.275 \pm 0.0460$ & $0.175 \pm 0.0343$ & 0.073 \\
Calcium & $0.107 \pm 0.0637$ & $0.159 \pm 0.0539$ & 0.541 \\
Phosphorus & $0.141 \pm 0.0677$ & $0.205 \pm 0.0572$ & 0.480 \\
Potassium & $0.835 \pm 0.0369$ & $0.833 \pm 0.0312$ & 0.963 \\
Sodium & $0.774 \pm 0.0196$ & $0.793 \pm 0.0165$ & 0.462 \\
Sulfur & $0.536 \pm 0.0542$ & $0.481 \pm 0.0458$ & 0.447 \\
Magnesium & $0.268 \pm 0.0768$ & $0.317 \pm 0.0649$ & 0.629 \\
\hline
\end{tabular}

Only serum Se was different $(P=0.046)$ between groups of animals; values were higher in low-RFI heifers (Table 4). Selenium intake was highly correlated with Se apparent absorption $(\mathrm{r}=0.91, P<0.001)$. Concentration of Se in serum was positively correlated with $\mathrm{Cu}(\mathrm{r}=0.56, P<0.01), \mathrm{Zn}(\mathrm{r}=0.45, P<0.05)$, $\mathrm{Mn}(\mathrm{r}=0.66, P<0.001)$, and $\mathrm{Co}(\mathrm{r}=0.65, P<0.001)$ apparent absorption. Serum concentrations of other minerals $(\mathrm{Cu}, \mathrm{Fe}, \mathrm{Mn}, \mathrm{Mo}, \mathrm{Zn}, \mathrm{P}, \mathrm{K}, \mathrm{Ca}, \mathrm{Mg}$, and $\mathrm{Na})$ were not different $(P>0.10)$ between the high- and low-RFI groups. Concentrations of $\mathrm{Se}, \mathrm{Zn}, \mathrm{Cu}, \mathrm{Mn}, \mathrm{Mo}$, $\mathrm{Fe}$, and Co in liver were similar $(P>0.10)$ for low- and high-RFI heifers (Table 5).

\section{DISCUSSION}

\section{Feed Intake}

Analyses of the diet showed that concentrations of all minerals in feed (Table 1 ) were above NRC requirements

Table 4. Least squares means $( \pm \mathrm{SEM})$ for minerals in serum of pregnant heifers with low and high residual feed intake (RFI)

\begin{tabular}{lccc}
\hline Item & Low RFI & High RFI & $P$-value \\
\hline RFI $(\mathrm{kg}$ of $\mathrm{DM} / \mathrm{d})$ & -1.18 & 1.24 & \\
Copper $(\mu \mathrm{g} / \mathrm{dL})$ & $98.4 \pm 4.72$ & $96.6 \pm 4.37$ & 0.785 \\
Iron $(\mu \mathrm{g} / \mathrm{dL})$ & $145 \pm 14.4$ & $143 \pm 13.3$ & 0.914 \\
Manganese $(\mu \mathrm{g} / \mathrm{dL})$ & $0.222 \pm 0.0581$ & $0.237 \pm 0.0538$ & 0.855 \\
Molybdenum $(\mu \mathrm{g} / \mathrm{dL})$ & $18.0 \pm 3.68$ & $22.5 \pm 3.41$ & 0.379 \\
Selenium $(\mu \mathrm{g} / \mathrm{dL})$ & $5.19 \pm 0.211$ & $4.59 \pm 0.195$ & 0.046 \\
Zinc $(\mu \mathrm{g} / \mathrm{dL})$ & $138 \pm 12.4$ & $127 \pm 11.5$ & 0.530 \\
Calcium $(\mathrm{mg} / \mathrm{dL})$ & $9.96 \pm 0.136$ & $9.86 \pm 0.115$ & 0.586 \\
Phosphorus $(\mathrm{mg} / \mathrm{dL})$ & $6.26 \pm 0.299$ & $6.37 \pm 0.252$ & 0.786 \\
Potassium $(\mathrm{mg} / \mathrm{dL})$ & $16.1 \pm 0.28$ & $16.0 \pm 0.24$ & 0.777 \\
Sodium $(\mathrm{mg} / \mathrm{dL})$ & $321 \pm 3.0$ & $324 \pm 2.5$ & 0.457 \\
Magnesium $(\mathrm{mg} / \mathrm{dL})$ & $2.33 \pm 0.065$ & $2.33 \pm 0.055$ & 0.933 \\
\hline
\end{tabular}

Table 5. Least squares means $( \pm \mathrm{SEM})$ of the concentrations of trace elements in liver (in $\mu \mathrm{g} / \mathrm{g}$, unless noted) for pregnant heifers with low and high residual feed intake (RFI)

\begin{tabular}{lccl}
\hline Item & Low RFI & High RFI & $P$-value \\
\hline RFI $(\mathrm{kg}$ of DM/d) & -1.18 & 1.24 & \\
Copper & $31.3 \pm 3.60$ & $31.9 \pm 3.31$ & 0.89 \\
Iron & $70.9 \pm 7.17$ & $69.4 \pm 6.59$ & 0.88 \\
Manganese & $1.88 \pm 0.087$ & $1.82 \pm 0.080$ & 0.62 \\
Molybdenum & $1.38 \pm 0.063$ & $1.35 \pm 0.058$ & 0.74 \\
Selenium & $0.197 \pm 0.0059$ & $0.191 \pm 0.0053$ & 0.42 \\
Zinc & $22.7 \pm 1.84$ & $27.1 \pm 1.69$ & 0.091 \\
Cobalt & $0.063 \pm 0.0024$ & $0.061 \pm 0.0022$ & 0.53 \\
\hline
\end{tabular}

for pregnant replacement heifers (NRC, 2000), and well below maximum tolerable concentrations (NRC, 2005). Mineral and trace element concentrations in water (Table 2) were below the maximum guideline limits for quality of water for livestock (Puls, 1994). Considering the low concentration of all minerals in water, it can be expected that ingestion of minerals through drinking water had a minor effect on total daily intake, and a negligible influence on the estimated apparent absorptions using an indirect (indicator) method.

A minimum of $84 \mathrm{~d}$ of daily feed intake monitoring is considered necessary to test for feed efficiency using RFI (Tatham et al., 2000) so that heifers can be classified as low or high RFI. The resulting 2 groups were used to evaluate differences in mineral utilization in the digestive tract. As RFI and mineral absorption may be influenced by breed (Berry and Crowley, 2013; Retallick et al., 2013), the breed composition of the heifers included in each experimental group was calculated. The average breed composition of the low-RFI group was 64\% (SEM = 6.4) Angus, 18\% (SEM = 6.8) Simmental, and $18 \%(\mathrm{SEM}=5.0)$ other breeds, whereas for the high RFI the average breed composition was $66 \%(\mathrm{SEM}=6.2)$ Angus, $23 \%(\mathrm{SEM}=6.6)$ Simmental, and $11 \%(\mathrm{SEM}=3.9)$ other breeds. The comparison between groups in the percentage of these breeds showed that differences were not significant $(P$ $=0.84,0.55$, and 0.30 for Angus, Simmental, and other breeds, respectively). Consequently, it can be expected that breed composition has no influence on the differences between experimental groups in RFI and in the absorption of trace elements.

\section{Digestibility}

Nkrumah et al. (2006) observed that low-RFI cattle were more efficient in digesting feed than average or high-RFI cattle. Herd (2009) concluded that differences in the processes of digestion and substrate availability in portal blood could explain, in part, divergent efficiency of feed utilization. These differences in the 
digestion of feed could be attributed to variations in the reticulorumen size (Fitzsimons et al., 2014) or in the rumen microbiome (McCann et al., 2014). Hendriks et al. (2013) suggested that such variation would be a consequence of the decrease in digestion associated with increased feed intake. However, other authors have reported that divergence in RFI was not associated with differences in whole-tract digestibility in beef heifers (Fitzsimons et al., 2013) or lactating cows (Thornhill et al., 2014). The lack of sensitivity of methods used to determine digestibility (especially by indirect methods) introduces challenges when measuring small differences in digestibility, and thus caution should be taken when attributing variation in digestibility as a major factor influencing differences in RFI in cattle (Herd, 2009).

Apparent absorption coefficients for $\mathrm{Fe}, \mathrm{Cu}$, and $\mathrm{Mn}$ were lower than the values reported by Standish et al. (1971) for steers fed different levels of Fe and P, and comparable or higher than the values of $\mathrm{Fe}, \mathrm{Cu}, \mathrm{Zn}$, and Mn described by Suttle (2010). Selenium apparent absorption was in agreement with values reported for lactating (Ivancic and Weiss, 2001) and nonlactating (Harrison and Conrad, 1984) dairy cows. The strong correlation between Se intake and apparent absorption indicates efficient utilization of this trace element by the pregnant heifers.

As the heifers were in the first trimester of gestation, it is reasonable to assume that $\mathrm{Mn}, \mathrm{Cu}$, and $\mathrm{Zn}$ would be important for embryonic and early fetal survival (Hostetler et al., 2003), as accretion of these elements in the conceptus is several fold greater than in other reproductive tissues. Cobalt is also considered a trace element important for reproduction (Hidiroglou, 1979). Several researchers reported an improvement in reproductive performance in dairy cows supplemented with Co, $\mathrm{Cu}, \mathrm{Zn}$, and Mn (Uchida et al., 2001; Ballantine et al., 2002; Kellogg et al., 2003; Griffiths et al., 2007). In contrast, Hackbart et al. (2010) did not observe any effect of $\mathrm{Cu}, \mathrm{Zn}, \mathrm{Mn}$, and Co from organic sources on embryo quality or luteal trace element concentration in pregnant dairy cows, although milk production increased significantly after calving.

In ruminants, the demand for $\mathrm{Mn}$ and $\mathrm{Cu}$ from the fetus increases during pregnancy (Hidiroglou and Knipfel, 1981). The increased intestinal absorption of $\mathrm{Cu}$, Zn, Mn, and Co in low-RFI pregnant heifers could have been driven by an increased demand for these trace elements by the fetus, although the mechanisms causing the enhanced absorption of trace elements in low-RFI heifers have not yet been elucidated.

Absorption of $\mathrm{Ca}$ and $\mathrm{P}$ were lower than the values cited by NRC (2000). This could be due to the greater $\mathrm{Ca}$ and $\mathrm{P}$ densities in the experimental diet relative to NRC recommendations for pregnant heifers. In con- trast, $\mathrm{Ca}$ apparent absorption was in close agreement with the mean values of 0.12 and 0.16 described by Martz et al. (1999) for nonlactating cows fed different dietary ratios of $\mathrm{Ca}$ and $\mathrm{P}$. Sodium and $\mathrm{K}$ were apparently absorbed to a greater extent than the other minerals, reflecting their high availability in the feed (Suttle, 2010). The absence of significant differences in apparent absorption of $\mathrm{P}, \mathrm{K}, \mathrm{Ca}, \mathrm{Mg}, \mathrm{S}$, and $\mathrm{Na}$ among heifers differing in RFI might indicate that these minerals are not directly related to the mechanisms underlying the differences in feed efficiency of these animals.

\section{Blood Circulating Minerals}

The mean values of Se in serum were close to the mean value reported by Van Saun et al. (1989) for pregnant dairy cows, and are in agreement with the reference values described by Stowe and Herdt (1992) for cattle. Pilarczyk et al. (2012) suggested that higher levels of both Se in serum and glutathione peroxidase enzyme activity observed in the first stage of lactation in dairy cows could be attributed to higher oxidative stress during this period. In another study with goats, ADG, feed efficiency, and glutathione peroxidase and superoxide dismutase activities in serum were elevated in response to supplemental selenomethionine (Yue et al., 2009). Thus, it is possible that the higher levels of serum Se in low-RFI heifers could be due to higher oxidative stress or a better capacity for protection against hydroperoxides (free radicals) formed upon exposure to $\mathrm{O}_{2}$.

Selenium plays an important role in growth, health, and reproduction of livestock (Moeini et al., 2009; Suttle, 2010). The correlation between Se in serum and $\mathrm{Cu}, \mathrm{Zn}$, and $\mathrm{Mn}$ apparent absorption suggests possible interactions between utilization of Se and other trace elements $(\mathrm{Cu}, \mathrm{Zn}$, and $\mathrm{Mn})$, warranting further research to better understand the roles of such interactions in feed efficiency.

According to reference values given by Puls (1994) and Kincaid (2000), Fe and Zn in serum were within normal physiological ranges. Copper in serum was above the suggested reference value for $\mathrm{Cu}$ deficiency in cattle given by Puls (1994).

Despite receiving recommended levels of dietary Mo, both RFI groups of pregnant heifers showed elevated serum Mo concentrations (Puls, 1994), which could predispose these animals to secondary $\mathrm{Cu}$ deficiency (Humphries et al., 1983; Dias et al., 2013). According to Puls (1994), $\mathrm{Cu}$ in serum may be biologically unavailable if serum Mo is greater than $0.1 \mathrm{mg} / \mathrm{L}$. Serum Mo was correlated with $\mathrm{Fe}(\mathrm{r}=0.62 ; P<0.01)$ and $\mathrm{S}$ intake $(\mathrm{r}=0.68 ; P<0.001)$, indicating that the last 2 minerals could affect Mo metabolism. Important 
interactions between dietary $\mathrm{Cu}, \mathrm{Mo}$, and $\mathrm{S}$ with a significant effect on performance of growing-finishing cattle were described by Dias et al. (2013).

\section{Liver Accumulation}

The lack of differences in the mineral status of liver could indicate that differences in the hepatic concentrations of these elements are not relevant indicators of the differences in feed efficiency between the 2 groups of heifers. Hackbart et al. (2010) observed that organic trace mineral supplementation ( $\mathrm{Zn}, \mathrm{Mn}, \mathrm{Cu}$, and $\mathrm{Co}$ ) increased milk production in midlactation, but did not affect liver trace mineral concentrations.

According to the reference values for trace elements in the liver of cattle described by Puls (1994), Fe and Co were within normal physiological ranges. The low concentration of $\mathrm{Mn}$ in liver could be a result of interactions with other minerals, and therefore not representative of Mn status. It may be possible that a high intake of Fe interfered with the uptake of $\mathrm{Mn}$ in liver, as observed by Hansen (2008) in pigs fed high dietary Fe. Moreover, it has been suggested recently that absorption of $\mathrm{Fe}, \mathrm{Mn}$, and $\mathrm{Cu}$ are mediated through the protein divalent metal transporter 1 (Hansen et al., 2010), which could explain some of the interactions between these minerals. Other researchers have observed that concentration of $\mathrm{Mn}$ in liver is not a good predictor of Mn status (Watson et al., 1973; Ahola et al., 2004). Regarding $\mathrm{Zn}$ concentration in liver, it is possible that its low concentration [compared with values reported by Puls (1994)] is related to the young age of the animals. Puschner et al. (2004) observed that Zn concentrations in the liver of calves increased with age. Hepatic Se concentration was considered the best predictor of fetal Se status due to the high correlation between maternal and fetal Se in liver (Gooneratne et al., 1989; Van Saun et al., 1989).

Information on trace element status in pregnant heifers and on changes in the metabolism of minerals, such as $\mathrm{Cu}$ during pregnancy (Hidiroglou, 1979), is scarce, making interpretation of the results for liver and serum difficult. The most relevant result relates to the observation that apparent absorption of $\mathrm{Cu}, \mathrm{Zn}, \mathrm{Mn}$, and Co is increased in low-RFI pregnant heifers, probably because these are trace elements essential to successful reproductive performance (Hidiroglou, 1979). Although it is difficult to identify the mechanisms involved, it is plausible that low-RFI heifers were able to improve provision of $\mathrm{Cu}, \mathrm{Zn}, \mathrm{Mn}$, and Co to their fetuses, as the absorption of these minerals was increased for this group of heifers. Only a limited number of studies have investigated the relationship between postweaning RFI and reproductive traits. Basarab et al. (2007) concluded that cows that produced efficient calves were in better body condition throughout their lifetime, and had less calf death loss compared with cows that produced inefficient progeny. Arthur et al. (2005) and Donoghue et al. (2011) found no differences in maternal productivity (pregnancy, calving, and weaning rates) between 2 groups of cows divergently selected for distinct RFI. Similarly, Basarab et al. (2012) concluded that large differences in RFI were not associated with changes in pregnancy or calving rates, calf mortality, and weight of calf weaned per cow exposed to breeding.

In conclusion, our study shows that whereas apparent absorption of $\mathrm{Ca}, \mathrm{P}, \mathrm{Na}, \mathrm{K}, \mathrm{S}, \mathrm{Mg}$, and Se were similar for both groups of animals, absorption of $\mathrm{Cu}, \mathrm{Zn}, \mathrm{Co}$, and Mn were increased in low-RFI (more feed efficient) pregnant heifers, suggesting that these animals may be more efficient in addressing the greater demand for minerals that prevails during early gestation. However, the relationships observed do not elucidate a causal link between feed RFI and mineral apparent absorption in the gut. Therefore, further research is required to understand the association between feed efficiency and mineral utilization in cattle, and whether trace elements may be involved in specific mechanisms related to feed efficiency. Our study also provides perspective for in-depth evaluation of mineral requirements in light of variation in feed efficiency of the bovine.

\section{ACKNOWLEDGMENTS}

This project was funded in part through the Growing Forward Program (Agricultural Adaptation Council, Guelph, ON, Canada); the Beef Cattle Research Council (Canadian Cattleman Association, Calgary, AB, Canada); the Agriculture and Agri-food Canada (Ottawa, ON, Canada); the Beef Farmers of Ontario (Guelph, ON, Canada); the Ontario Ministry of Agriculture, Food and Rural Affairs (Guelph, ON, Canada); and the Canada Research Chairs Program of the Natural Sciences and Engineering Research Council of Canada (Ottawa, ON, Canada).

\section{REFERENCES}

Ahola, J. K., D. S. Baker, P. D. Burns, R. G. Mortimer, R. M. Enns, J. C. Whittier, T. W. Geary, and T. E. Engle. 2004. Effect of copper, zinc, and manganese supplementation and source on reproduction, mineral status, and performance in grazing beef cattle over a twoyear period. J. Anim. Sci. 82:2375-2383.

AOAC International. 2006. Official Methods of Analysis. 18th ed., Current Through Revision 1. AOAC Int., Gaithersburg, MD.

Arthur, P. F., R. M. Herd, J. F. Wilkins, and J. A. Archer. 2005. Maternal productivity of Angus cows divergently selected for postweaning residual feed intake. Aust. J. Exp. Agric. 45:985-993.

Ballantine, H. T., M. T. Socha, D. J. Tomlinson, A. B. Jonhson, A. S. Fielding, J. K. Shearer, and S. R. Van Amstel. 2002. Effects of feeding complexed zinc, manganese, copper, and cobalt to late 
gestation and lactating dairy cows on claw integrity, reproduction, and lactation performance. Prof. Anim. Sci. 18:211-218.

Basarab, J. A., K. A. Beauchemin, V. S. Baron, K. H. Ominski, L. L. Guan, S. P. Miller, and J. J. Crowley. 2013. Reducing GHG emissions through genetic improvement for feed efficiency: Effects on economically important traits and enteric methane production. Animal 7(Suppl 2):303-315.

Basarab, J. A., C. Fitzsimmons, C. S. Whisnant, and R. P. Wettemann. 2012. Interactions with other traits: Reproduction and fertility. Pages 123-144 in Feed Efficiency in the Beef Industry. R. A. Hill, ed. John Wiley \& Sons Inc., Ames, IA.

Basarab, J. A., D. McCartney, E. K. Okine, and V. S. Baron. 2007. Relationships between progeny residual feed intake and dam productivity traits. Can. J. Anim. Sci. 87:489-502.

Berry, D. P., and J. J. Crowley. 2013. Genetics of feed efficiency in dairy and beef cattle. J. Anim. Sci. 91:1594-1613.

Bottje, W. G., and G. E. Carstens. 2012. Variation in metabolism: Biological efficiency of energy production and utilization that affects feed efficiency. Pages 251-273 in Feed Efficiency in the Beef Industry. R. A. Hill, ed. John Wiley \& Sons Inc., Ames, IA.

Canadian Council on Animal Care. 1993. Guide to the Care and Use of Experimental Animals. Vol. 1. E. D. Olfert, B. M. Cross, and A. McWilliams, ed. Canadian Council of Animal Care, Ottawa, Canada.

Davis, M. E., M. P. Wick, and M. G. Maquivar. 2012. Hormonal regulation of feed efficiency. Pages 225-250 in Feed Efficiency in the Beef Industry. R. A. Hill, ed. John Wiley \& Sons Inc., Ames, IA.

Dias, R. S., S. López, Y. R. Montanholi, B. Smith, L. S. Haas, S. P. Miller, and J. France. 2013. A meta-analysis of the effects of dietary copper, molybdenum, and sulfur on plasma and liver copper, weight gain, and feed conversion in growing-finishing cattle. J. Anim. Sci. 91:5714-5723.

Donoghue, K. A., P. F. Arthur, J. F. Wilkins, and R. M. Herd. 2011. Onset of puberty and early-life reproduction in Angus females divergently selected for post-weaning residual feed intake. Anim. Prod. Sci. 51:183-190.

Fitzsimons, C., D. A. Kenny, M. H. Deighton, A. G. Fahey, and M. McGee. 2013. Methane emissions, body composition, and rumen fermentation traits of beef heifers differing in residual feed intake. J. Anim. Sci. 91:5789-5800.

Fitzsimons, C., D. A. Kenny, and M. McGee. 2014. Visceral organ weights, digestion and carcass characteristics of beef bulls differing in residual feed intake offered a high concentrate diet. Animal 8:949-959.

Gonano, C. V., Y. R. Montanholi, F. S. Schenkel, B. A. Smith, J. P. Cant, and S. P. Miller. 2014. The relationship between feed efficiency and the circadian profile of blood plasma analytes measured in beef heifers at different physiological stages. Animal 8:16841698.

Gooneratne, S. R., W. T. Buckley, and D. A. Christensen. 1989. Review of copper deficiency and metabolism in ruminants. Can. J. Anim. Sci. 69:819-845.

Greenwood, S. L., T. C. Wright, N. G. Purdie, J. Doelman, J. P. Cant, and B. W. McBride. 2009. Lactation induces upregulation of the ubiquitin-mediated proteolytic pathway in skeletal muscle of dairy cows but does not alter hepatic expression. Can. J. Anim. Sci. 89:309-313.

Griffiths, L. M., S. H. Loeffler, M. T. Socha, D. J. Tomlinson, and A. B. Johnson. 2007. Effects of supplementing complexed zinc, manganese, copper and cobalt on lactation and reproductive performance of intensively grazed lactating dairy cattle on the South Island of New Zealand. Anim. Feed Sci. Technol. 137:69-83.

Hackbart, K. S., R. M. Ferreira, A. A. Dietsche, M. T. Socha, R. D. Shaver, M. C. Wiltbank, and P. M. Fricke. 2010. Effect of dietary organic zinc, manganese, copper, and cobalt supplementation on milk production, follicular growth, embryo quality, and tissue mineral concentrations in dairy cows. J. Anim. Sci. 88:3856-3870.

Hansen, S. L. 2008. Nutritional interrelationships between iron, copper and manganese in domestic livestock. PhD Thesis. North Carolina State Univ., Raleigh, NC.
Hansen, S. L., N. Trakooljul, H.-C. S. Liu, J. A. Hicks, M. S. Ashwell, and J. W. Spears. 2010. Proteins involved in iron metabolism in beef cattle are affected by copper deficiency in combination with high dietary manganese, but not by copper deficiency alone. J. Anim. Sci. 88:275-283.

Harrison, J. H., and H. R. Conrad. 1984. Effect of selenium intake on selenium utilization by the non-lactating dairy cow. J. Dairy Sci. $67: 219-223$.

Hegarty, R. S., J. P. Goopy, R. M. Herd, and B. McCorkell. 2007. Cattle selected for lower residual feed intake have reduced daily methane production. J. Anim. Sci. 85:1479-1486.

Hendriks, J., M. M. Scholtz, and F. W. C. Neser. 2013. Possible reasons for differences in residual feed intake: An overview. S. Afr. J. Anim. Sci. 43:103-106.

Herd, R. M. 2009. Residual feed intake. Pages 89-109 in Resource Allocation Theory Applied to Farm Animal Production. W. M. Rauw, ed. CABI, Wallingford, UK.

Herd, R. M., J. A. Archer, and P. F. Arthur. 2003. Reducing the cost of beef production through genetic improvement in residual feed intake: opportunity and challenges to application. J. Anim. Sci. 81:E9-E17.

Herd, R. M., V. H. Oddy, and P. F. Arthur. 2004. Biological basis for variation in residual feed intake in beef cattle. 1 . Review of potential mechanisms. Aust. J. Exp. Agric. 44:423-430.

Hidiroglou, M. 1979. Trace element deficiencies and fertility in ruminants: a review. J. Dairy Sci. 62:1195-1206.

Hidiroglou, M., and J. E. Knipfel. 1981. Maternal-fetal relationships of copper, manganese, and sulfur in ruminants: A review. J. Dairy Sci. 64:1637-1647.

Hill, R. A. 2012. Introduction. Pages 1-5 in Feed Efficiency in the Beef Industry. R. A. Hill, ed. John Wiley \& Sons Inc., Ames, IA.

Hostetler, C. E., R. L. Kincaid, and M. A. Mirando. 2003. The role of essential trace elements in embryonic and fetal development in livestock. Vet. J. 166:125-139.

Humphries, W. R., M. Phillippo, B. W. Young, and I. Bremner. 1983. The influence of dietary iron and molybdenum on copper metabolism in calves. Br. J. Nutr. 49:77-86.

Ivancic, J. Jr., and W. P. Weiss. 2001. Effect of dietary sulfur and selenium concentrations on selenium balance of lactating Holstein cows. J. Dairy Sci. 84:225-232.

Kellogg, D. W., M. T. Socha, D. J. Tomlinson, and A. B. Johnson. 2003. Effect of feeding a combination of cobalt glucoheptonate and metal specific amino acid complexes of zinc, manganese and copper on lactation and reproductive performance of dairy cows: eight trial summary. Prof. Anim. Sci. 19:1-9.

Kincaid, R. L. 2000. Assessment of trace mineral status of ruminants: A review. Proc. Am. Soc. Anim. Sci. 77(E-Suppl.):1-10. Accessed Apr. 2016. http://www.fourseasonco.com.au/infosheets/trace_ mineral_20120626.pdf.

Knapp, J. R., G. L. Laur, P. A. Vadas, W. P. Weiss, and J. M. Tricarico. 2014. Enteric methane in dairy cattle production: Quantifying the opportunities and impact of reducing emissions. J. Dairy Sci. 97:3231-3261.

Koch, R. M., L. A. Swiger, D. Chambers, and K. E. Gregory. 1963. Efficiency of feed use in beef cattle. J. Anim. Sci. 22:486-494.

Kolath, W. H., M. S. Kerley, J. W. Golden, and D. H. Keisler. 2006 The relationship between mitochondrial function and residual feed intake in Angus steers. J. Anim. Sci. 84:861-865.

Kotb, A. R., and T. D. Luckey. 1972. Markers in nutrition. Nutr. Abstr. Rev. 42:813-845.

Martz, F. A., A. T. Belo, M. F. Weiss, and R. L. Belyea. 1999. True absorption of calcium and phosphorus from corn silage fed to nonlactating, pregnant dairy cows. J. Dairy Sci. 82:618-622.

McCann, J. C., L. M. Wiley, T. D. Forbes, F. M. Rouquette Jr, and L. O. Tedeschi. 2014. Relationship between the rumen microbiome and residual feed intake-efficiency of Brahman bulls stocked on Bermudagrass pastures. PLOS One 9:e91864. http://dx.doi org/10.1371/journal.pone.0091864.

Meyer, A. M., J. S. Caton, B. W. Hess, S. P. Ford, and L. P. Reynolds. 2012. Epigenetics and effects on the neonate that may impact feed 
efficiency. Pages 199-223 in Feed Efficiency in the Beef Industry. R. A. Hill, ed. John Wiley \& Sons Inc., Ames, IA.

Moeini, M. M., H. Karami, and E. Mikaeili. 2009. Effect of selenium and vitamin $\mathrm{E}$ supplementation during the late pregnancy on reproductive indices and milk production in heifers. Anim. Reprod. Sci. 114:109-114.

Montanholi, Y. R., S. Lam, V. Peripolli, G. Vander Voort, and S. P. Miller. 2013b. Associations between chemical composition and physical properties of milk and colostrum with feed efficiency in beef cows. Can. J. Anim. Sci. 93:487-492.

Montanholi, Y. R., R. Palme, L. S. Haas, K. C. Swanson, G. Vander Voort, and S. P. Miller. 2013a. On the relationships between glucocorticoids and feed efficiency in beef cattle. Livest. Sci. 155:130136.

Montanholi, Y. R., K. C. Swanson, F. S. Schenkel, B. W. McBride, T. R. Caldwell, and S. P. Miller. 2009. On the determination of residual feed intake and associations of infra-red thermography with efficiency and ultrasound traits in beef bulls. Livest. Sci. 125:22-30.

National Research Council. 2000. Nutrient Requirements of Beef Cattle: Update 2000. 7th rev. ed. Natl. Acad. Press, Washington, DC.

National Research Council. 2005. Mineral Tolerance of Animals. 2nd rev. ed. Natl. Acad. Press, Washington, DC.

Nkrumah, J. D., E. K. Okine, G. W. Mathison, K. Schmid, C. Li, J. A. Basarab, M. A. Price, Z. Wang, and S. S. Moore. 2006. Relationships of feedlot feed efficiency, performance and feeding behavior with digestion, energy partitioning, methane production and metabolic rate in beef cattle. J. Anim. Sci. 84:145-153.

Pilarczyk, B., D. Jankowiak, A. Tomza-Marciniak, R. Pilarczyk, P. Sablik, R. Drozd, A. Tylkowska, and M. Skólmowska. 2012. Selenium concentration and glutathione peroxidase (GSH-Px) activity in serum of cows at different stages of lactation. Biol. Trace Elem. Res. 147:91-96.

Puls, R. 1994. Mineral Levels in Animal Health. Diagnostic Data. 2nd ed. Sherpa International, Clearbrook, BC, Canada.

Puschner, B., Y. Choi, J. H. Tegzes, and M. C. Thurmond. 2004. Influence of age, sex, and production class on liver zinc concentration in calves. J. Vet. Diagn. Invest. 16:278-282.

Retallick, K. M., D. B. Faulkner, S. L. Rodriguez-Zas, J. D. Nkrumah, and D. W. Shike. 2013. The effect of breed and individual heterosis on the feed efficiency, performance, and carcass characteristics of feedlot steers. J. Anim. Sci. 91:5161-5166.

Richardson, E. C., and R. M. Herd. 2004. Biological basis for variation in residual feed intake in beef cattle. 2. Synthesis of results following divergent selection. Aust. J. Exp. Agric. 44:431-440.
Sainz, R. D. 2012. Modeling feed efficiency. Pages 275-285 in Feed Efficiency in the Beef Industry. R. A. Hill, ed. John Wiley \& Sons Inc., Ames, IA

SAS Institute Inc. 2011. SAS/STAT 9.3 User's Guide. SAS Institute Inc, Cary, NC.

Spears, J. W. 1996. Organic trace minerals in ruminant nutrition. Anim. Feed Sci. Technol. 58:151-163.

Standish, J. F., C. B. Ammerman, A. Z. Palmer, and C. F. Simpson. 1971. Influence of dietary iron and phosphorus on performance, tissue mineral composition and mineral absorption in steers. J. Anim. Sci. 33:171-178.

Stowe, H. D., and T. H. Herdt. 1992. Clinical assessment of selenium status of livestock. J. Anim. Sci. 70:3928-3933.

Suttle, N. F. 2010. Mineral Nutrition of Livestock. 4th ed. CABI Publishing, Wallingford, UK.

Tatham, B. G., J. J. Davis, and G. R. Ferrier. 2000. Commercial application of net feed intake assessment, biochemical relationships and economic implications of using tested Angus bulls. Asian-australas. J. Anim. Sci. 13:327-330.

Thornhill, J. B., L. C. Marett, M. J. Auldist, J. S. Greenwood, J. E. Pryce, B. J. Hayes, and W. J. Wales. 2014. Whole-tract dry matter and nitrogen digestibility of lactating dairy cows selected for phenotypic divergence in residual feed intake. Anim. Prod. Sci. 54:1460-1464.

Uchida, K., P. Mandebvu, C. S. Ballard, C. J. Sniffen, and M. P. Carter. 2001. Effect of feeding a combination of zinc, manganese and copper amino acid complexes, and cobalt glucoheptonate on performance of early lactation high production cows. Anim. Feed Sci. Technol. 93:193-203.

Underwood, E. J., and N. F. Suttle. 1999. The Mineral Nutrition of Livestock. 3rd ed. CAB International, Wallingford. UK.

Van Saun, R. J., T. H. Herdt, and H. D. Stowe. 1989. Maternal and fetal selenium concentrations and their interrelationships in dairy cattle. J. Nutr. 119:1128-1137.

Watson, L. T., C. B. Ammerman, J. P. Feaster, and C. E. Roessler. 1973. Influence of manganese intake on metabolism of manganese and other minerals in sheep. J. Anim. Sci. 36:131-136.

Yue, W., C. Zhang, L. Shi, Y. Ren, Y. Jiang, and D. O. Kleemann. 2009. Effect of supplemental selenomethionine on growth performance and serum antioxidant status in Taihang black goats. Asian-australas. J. Anim. Sci. 22:365-370. 